\title{
Newborn patients exhibit an unusual pattern of interleukin 10 and interferon $\gamma$ serum levels in response to cardiac surgery
}

\author{
A. J. Alcaraz, $\mathrm{MD}^{\mathrm{a}}$ \\ L. Sancho, MD, PhDa ${ }^{*}$ \\ L. Manzano, MD, PhD b,c \\ F. Esquivel, $\mathrm{PhD}^{\mathrm{C}}$ \\ A. Carrillo, MD, $\mathrm{PhD}^{\mathrm{a}}$ \\ A. Prieto, $\mathrm{PhD}^{\mathrm{C}}$ \\ E. D. Bernstein, $\mathrm{MD}, \mathrm{PhD}^{\mathrm{C}}$ \\ M. Alvarez-Mon, $\mathrm{MD}, \mathrm{PhD}^{\mathrm{c}, \mathrm{d}}$
}

From the Department of Pediatrics and Pediatric Surgery, Pediatric Intensive Care Unit, Hospital General Universitario Gregorio Marañóna; Service of Medicine/ Clinical Immunology and Oncology, Hospital Universitario Príncipe de Asturias, University of Alcalá, Alcalá de Henares ; Service of Internal Medicine, Hospital Universitario Ramón y Cajal, University of Alcaláb; and Laboratory of Clinical Immunology, Department of Medicine, University of Alcalá, Alcalá de Henares, Madrid, Spain

This work was partially supported by FIS CICYT, and FEDER-SALUD.

Received for publication Feb 14, 2001; revisions requested March 21, 2001; revision received Aug 1, 2001; accepted for publication Aug 31, 2001

Address for reprints: M. Alvarez-Mon, MD, $\mathrm{PhD}$, Departamento de Medicina, Universidad de Alcalá, Alcalá de Henares, 18.871, Madrid, Spain (E-mail: mams@tsai.es).

*Both authors share the authorship of this article.

J Thorac Cardiovasc Surg 2002;123:451-8

Copyright (C) 2002 by The American Association for Thoracic Surgery

0022-5223/2002\$35.00 + $0 \quad \mathbf{1 2 / 1 / 1 2 0 0 0 6}$

doi:10.1067/mtc.2002.120006
Objective: The aim of this study was to determine the clinical significance of serum levels of interleukin 10 and interferon $\gamma$ in pediatric patients undergoing cardiopulmonary bypass.

Methods: We divided the patients into 2 groups: 8 neonates and 19 nonnewborn children. Interleukin 10 and interferon $\gamma$ serum levels were quantified before sternotomy, at admission to the pediatric intensive care unit (30 minutes postoperatively), 24 hours after the onset of the operation, and 3 days after the operation.

Results: Newborn patients displayed significantly greater amounts of serum interleukin 10 than older children, not only in regard to the peak level achieved but also at every postoperative time point analyzed. In contrast, no significant changes in interferon $\gamma$ serum levels were observed in neonates at any time point, whereas nonnewborn pediatric patients showed a significant increase in interferon $\gamma$ serum concentrations immediately after the operation. This unusual pattern of cytokine response in newborn patients was not associated with modifications in cortisol serum levels. Furthermore, although neonates had significantly different surgical and clinical variables than did the nonnewborn pediatric patients, the variation in interleukin 10 production in neonates could not be accounted for by differences in the magnitude of surgical injury. In the group of neonates, there were significant positive correlations between peak interleukin 10 serum levels and both partial pressure of arterial oxygen/fraction of inspired oxygen ratio and postoperative body weight gain.

Conclusions: Newborn patients undergoing cardiopulmonary bypass exhibit a distinctive biologic response pattern characterized by high levels of serum interleukin 10 without changes in serum interferon $\gamma$. This cytokine imbalance could have potential clinical implications.

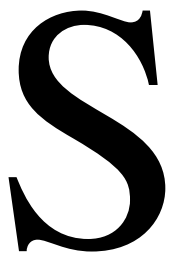

urgical trauma represents a model of tissue injury and repair. In the pathogenesis of this process, both neuroendocrine and immunoinflammatory systems are involved at the local and systemic levels. ${ }^{1-4}$ Major body injuries, including surgical intervention, evoke reproducible metabolic, hormonal, and immunologic responses that are recognized as the stress response. ${ }^{1,2}$ The intensity of this response appears to be 
TABLE 1. Baseline clinical and surgical characteristics of pediatric patients

\begin{tabular}{|c|c|c|c|c|c|c|c|c|}
\hline & Weight (kg) & Age (mo) & Sex & Diagnosis & Operation & $\begin{array}{c}\text { Time on } \\
\text { bypass } \\
\text { (min) }\end{array}$ & $\begin{array}{c}\text { Crossclamp } \\
\text { time } \\
\text { (min) }\end{array}$ & $\begin{array}{c}\text { Minimum } \\
\text { temperature }\left({ }^{\circ} \mathrm{C}\right)\end{array}$ \\
\hline \multirow[t]{8}{*}{ Neonates } & 2.8 & 0.5 & $\mathrm{M}$ & TGA & Arterial switch & 100 & 70 & 16 \\
\hline & 2.7 & 0.3 & $\mathrm{M}$ & $\mathrm{TGA}$ & Arterial switch & 131 & 65 & 18 \\
\hline & 3.3 & 0.3 & $\mathrm{~F}$ & $\mathrm{TGA}$ & Arterial switch & 155 & 63 & 18 \\
\hline & 3.9 & 0.4 & $\mathrm{~F}$ & TGA & Arterial switch & 120 & $62^{*}$ & 18 \\
\hline & 3.3 & 0.5 & $\mathrm{M}$ & $\mathrm{TGA}$ & Arterial switch & 90 & $50^{*}$ & 16 \\
\hline & 3.5 & 0.2 & $\mathrm{M}$ & $\mathrm{TGA}$ & Arterial switch & 122 & $70^{*}$ & 15 \\
\hline & 3.1 & 0.2 & $\mathrm{M}$ & $\mathrm{TGA}$ & Arterial switch & 114 & 60 & 18 \\
\hline & 3.4 & 0.3 & $\mathrm{~F}$ & TGA & Arterial switch & 126 & 66 & 16 \\
\hline Mean \pm SD & $3.25 \pm 0.39$ & $0.37 \pm 0.10$ & & & & $119.75 \pm 19.72$ & $63.25 \pm 6.43$ & $16.88 \pm 1.25$ \\
\hline \multirow{19}{*}{ Nonneonates } & 5.7 & 11 & $\mathrm{M}$ & VSD & VSD repair & 58 & 36 & 30 \\
\hline & 5.3 & 4.5 & $\mathrm{~F}$ & $\mathrm{TGA}$ & Mustard procedure & 72 & $43^{*}$ & 25 \\
\hline & 6.7 & 13 & $\mathrm{M}$ & TOF & TOF repair & 99 & 51 & 24 \\
\hline & 7.3 & 7 & $\mathrm{M}$ & VSD and ASD & VSD and ASD repair & 66 & 38 & 28 \\
\hline & 18 & 48 & $\mathrm{~F}$ & $\mathrm{TA}$ & Fontan procedure & 75 & 44 & 28 \\
\hline & 9.5 & 15 & $\mathrm{M}$ & VSD & VSD repair & 55 & 30 & 30 \\
\hline & 10.9 & 22 & $\mathrm{M}$ & TOF & TOF repair & 82 & 40 & 28 \\
\hline & 13.5 & 34 & $\mathrm{~F}$ & VSD & VSD repair & 62 & 34 & 28 \\
\hline & 8.1 & 10 & $\mathrm{~F}$ & VSD & VSD repair & 60 & 32 & 28 \\
\hline & 8.7 & 11 & $\mathrm{M}$ & VSD & VSD repair & 67 & 38 & 28 \\
\hline & 8.8 & 14 & $\mathrm{~F}$ & TOF & TOF repair & 85 & 46 & 28 \\
\hline & 55 & 144 & $\mathrm{~F}$ & VSD and SAoS & VSD and SAoS repair & 55 & 41 & 32 \\
\hline & 18 & 60 & $\mathrm{M}$ & ASD & ASD repair & 40 & 20 & 33 \\
\hline & 22 & 85 & $\mathrm{~F}$ & LV-RA shunt & LV-RA shunt repair & 32 & 12 & 34 \\
\hline & 21 & 73 & $\mathrm{~F}$ & ASD & ASD repair & 30 & 5 & 30 \\
\hline & 52 & 167 & $\mathrm{~F}$ & PSVS & PSVS repair & 48 & 23 & 28 \\
\hline & 20 & 57 & $\mathrm{~F}$ & ASD & ASD repair & 45 & 22 & 33 \\
\hline & 28 & 88 & $\mathrm{M}$ & ASD & ASD repair & 40 & 20 & 33 \\
\hline & 32 & 107 & $\mathrm{M}$ & ASD & ASD repair & 34 & 15 & 33 \\
\hline Mean \pm SD & $18.45 \pm 14.55$ & $51.08 \pm 48.64$ & & & & $58.16 \pm 19.16$ & $31.05 \pm 12.76$ & $29.53 \pm 2.84$ \\
\hline
\end{tabular}

$T G A$, Transposition of the great arteries; VSD, ventricular septal defect; TOF, tetralogy of Fallot; $A S D$, atrial septal defect; TA, tricuspid atresia; $S A o S$, subaortic stenosis; $L V$, left ventricle; $R A$, right atrium; $P S V S$, pulmonary supravalvular stenosis.

*Total circulatory arrest was performed.

proportionally related to the extension of tissue damage. ${ }^{4,5}$ This stress response may be necessary for recovery of tissue after challenge and therefore is of survival value., ${ }^{2,3,5}$ However, when the resultant physiologic response is extensive and sustained, it may become injurious and contribute to the critical progression of the disease and, ultimately, to the death of the patient. ${ }^{2-4}$

Cardiac surgery is one of the most severe surgical stresses to which a child can be exposed and is clinically associated with systemic responses that can influence the postoperative course. ${ }^{6-8}$ It is widely recognized that cardiopulmonary bypass (CPB) activates a number of inflammatory pathways, including molecules of the complement system, ${ }^{8}$ kallikrein cascade, eicosanoid pathway, ${ }^{9}$ and cellular elements of the immune system, including monocytes- macrophages and $\mathrm{T}$ cells and polymorphonuclear neutrophils and platelets. ${ }^{8,10}$

Cytokines are molecules involved in the regulation of the immune inflammatory response. These molecules are secreted by different cells, including lymphocytes and accessory cells, and act on either the cytokine-producing cell (autocrine actions) or on other immune and nonimmune target cells (paracrine actions). ${ }^{11}$ Accessory cells produce interleukin (IL) $1 \beta$, IL-6, IL-10, and tumor necrosis factor (TNF) $\alpha .{ }^{11} \mathrm{~T}$ lymphocytes are also relevant cytokine producers, and several patterns of secretion have been defined. T-helper $1\left(\mathrm{~T}_{\mathrm{H}} 1\right)$ cells mainly secrete IL-2, interferon (IFN) $\gamma$, and lymphotoxin, whereas $\mathrm{T}_{\mathrm{H}} 2$ cells induce IL-4, IL-5, IL-6, IL-9, IL-10, and IL-13 secretion. ${ }^{12,13}$ The cytokine production of $\mathrm{T}_{\mathrm{H}} 1$ and $\mathrm{T}_{\mathrm{H}} 2$ lymphocytes appears to show 
mutual functional downregulation. It has been claimed that IFN- $\gamma$ suppresses the proliferation and function of $\mathrm{T}_{\mathrm{H}^{2}}$ cells, and in contrast, IL-10 inhibits that of $\mathrm{T}_{\mathrm{H}} 1$ lymphocytes. $^{13}$

IL-10, a 35- to 40-kd protein, is considered a relevant anti-inflammatory cytokine. IL-10 shows an inhibitory effect on monocyte class II major histocompatibility complex expression and on the production of reactive nitrogen oxides. ${ }^{13,14}$ In addition, this molecule upregulates the expression of both IL-1 receptor antagonist and soluble membrane-bound TNF receptors (sTNFR-55 and sTNFR75). ${ }^{14,15}$

By contrast, IFN- $\gamma$ is a potent proinflammatory molecule that upregulates the expression of major histocompatibility complex class II antigens on macrophages ${ }^{16}$ and increases the release of TNF- $\alpha$ and IL-1 by these cells. ${ }^{12,16}$ Furthermore, this cytokine promotes the differentiation of undefined $\mathrm{T}_{\mathrm{H}}$ cells into activated $\mathrm{T}_{\mathrm{H}} 1$ cells. ${ }^{13}$

There is increasing evidence that the characteristics of immune response to stress signals appear to be dependent on the age and nutritional status of the subject. ${ }^{17,18}$ The functional state of the immune system varies with age, including the pattern of production and response to cytokines. ${ }^{19-23}$ In this regard, deficient production of IFN- $\gamma$ has been observed in neonates. ${ }^{19,23,24}$ Also, it is worth noting that children usually show a more prolonged but less severe biologic response than neonates. ${ }^{17,18}$ On the other hand, pediatric patients with congenital heart disease are frequently undernourished, ${ }^{25}$ with associated immune system disturbances. ${ }^{26}$ Thus, it is possible to suggest that different patterns of IL-10 and IFN- $\gamma$ responses to surgical stress might be found during the early stages of life.

On the basis of this hypothesis, we have performed a prospective descriptive study to determine serum concentrations of IL-10 and IFN- $\gamma$ before and after cardiac surgery in neonates and nonnewborn pediatric patients undergoing hypothermic CPB. The potential clinical significance of the serum levels of these cytokines was also analyzed.

\section{Methods \\ Patients}

Twenty-seven children undergoing corrective surgical repair for congenital heart defects with hypothermic CPB were studied from June 1997 to November 1997 at Gregorio Marañón University Hospital in Madrid. Patients were consecutively studied in order of presentation. The patients included in this study had no clinical or microbiologic evidence of concomitant associated infectious disease and were not receiving immunosuppressive or anti-inflammatory drugs before surgical intervention.

The 27 patients were divided into 2 groups: neonates (8 patients) and nonneonates (19 patients, Table 1). Furthermore, children from the nonneonate group were analyzed separately on the basis of the presence or absence of congenital cyanotic heart disease.
The local ethics committee approved the study. A legal guardian for each patient gave informed consent for the experimental protocol.

\section{Anesthetic and CPB Techniques}

Patients weighing more than $10 \mathrm{~kg}$ were premedicated with midazolam $(0.7 \mathrm{mg} / \mathrm{kg}$, oral route). In all other patients anesthesia was induced without premedication. Induction was completed with etomidate $(0.3 \mathrm{mg} / \mathrm{kg})$, and tracheal intubation was facilitated with pancuronium $(0.1 \mathrm{mg} / \mathrm{kg})$. Anesthesia was maintained with oxygen, high-dose fentanyl $(100 \mu \mathrm{g} / \mathrm{kg})$, and pancuronium. Central venous catheters were introduced through the internal jugular vein, and radial or femoral arterial catheters were placed.

CPB equipment consisted of a roller pump (Cobe Stöckert Instrument, Rungis, France) and an appropriately sized Dideco hollow-fiber oxygenator with an integral cardiotomy reservoir (Dideco, Mirandola, Italy). The tubing of the extracorporeal circuit was constructed of polyvinyl chloride (Cobe Laboratories, Ltd, Gloucester, United Kingdom). The priming solution was a mixture of 5\% albumin in Plasmalyte A solution, and packed red blood cells were added to achieve a hematocrit level approximating the targeted temperature and falling within the range of $20 \%$ to $30 \%$. Packed red blood cells were added to the priming solution in all patients.

Body temperature was monitored continuously with a nasopharyngeal and vesical probe. Moderate hypothermia was induced in nonnewborns $\left(23^{\circ} \mathrm{C}-34^{\circ} \mathrm{C}\right)$. In newborn patients lower temperatures $\left(15^{\circ} \mathrm{C}-18^{\circ} \mathrm{C}\right)$ were induced. Core cooling and rewarming was achieved with an oxygenator heat-exchanger and with a warmingcooling blanket to reach a vesical-nasopharyngeal temperature of $36.5^{\circ} \mathrm{C}$ before terminating CPB. A flow of $2.4 \mathrm{~L} / \mathrm{m}^{2}$ per minute was maintained, except where a period of low perfusion or circulatory arrest was considered necessary. Anticoagulation was achieved with an initial bolus of $300 \mathrm{IU} / \mathrm{kg}$ of heparin injected into the right atrium before cannulation, and repeated doses were administered when the activated clotting time was shorter than 400 seconds. Heparin was neutralized with an injection of protamine sulfate within 5 minutes after the end of perfusion. Myocardial protection was achieved by means of Abboplegisol solution (temperature $4^{\circ} \mathrm{C}$ ), with an initial dose of 25 to $30 \mathrm{~mL} / \mathrm{kg}$. Conventional ultrafiltration during the rewarming phase of CPB was performed in all patients.

After cardiac surgery was completed, body temperature was allowed to recover, and aortic crossclamping was stopped. Twelve patients were separated from CPB during infusion of dopamine, 10 patients during infusion of dopamine and milrinone or dobutamine, and 5 patients without any vasoactive drug. CPB was discontinued when the hemodynamic state was stable, and systemic perfusion pressures between 50 and $70 \mathrm{~mm} \mathrm{Hg}$ were maintained. Thereafter, the patients were transported to the pediatric intensive care unit (PICU) in stable circulatory condition. Surgical data (type of intervention, $\mathrm{CPB}$ and aortic crossclamping time, minimum temperature on bypass, and presence or absence of circulatory arrest) of each patient and each group's mean \pm SD are shown in Table 1.

\section{PICU Management}

At the arrival to the PICU, all patients began mechanical ventilation, ensuring adequate ventilation and oxygenation. They 
TABLE 2. Postoperative clinical data in pediatric patients

\begin{tabular}{|c|c|c|c|c|c|c|c|c|}
\hline & $\begin{array}{l}\text { Post/pre } \\
\text { BW (\%) }\end{array}$ & $\begin{array}{l}\text { Postoperative } \\
\text { ICU length of } \\
\text { stay (d) }\end{array}$ & $\begin{array}{l}\text { Mechanical } \\
\text { ventilation } \\
\text { (d) }\end{array}$ & $\begin{array}{c}\text { Postoperative } \\
\text { blood loss at } \\
\text { first day (mL/kg) }\end{array}$ & $\begin{array}{c}\text { Dopamine }>10 \\
\mu \mathrm{g} \cdot \mathrm{kg}^{-1} \cdot \mathrm{min}^{-1} \text { or } \\
\text { epinephrine }\end{array}$ & $\begin{array}{l}\text { Postoperative } \\
\text { infection* }\end{array}$ & $\begin{array}{l}\mathrm{PaO}_{2} / \mathrm{FiO}_{2} \text { at } \\
\text { third hour }\end{array}$ & $\begin{array}{l}\mathrm{PaO}_{2} / \mathrm{FiO}_{2} \\
\text { at } 18 \text { hours }\end{array}$ \\
\hline Neonates & $122.2 \pm 3.2$ & $10.63 \pm 3.29$ & $6.25 \pm 1.83$ & $21.44 \pm 8.43$ & $5 / 8$ & $2 / 8$ & $197.0 \pm 23.6$ & $168.9 \pm 24.6$ \\
\hline Nonneonates & $106.4 \pm 5.6$ & $5.84 \pm 4.07$ & $2.24 \pm 3.10$ & $19.13 \pm 10.51$ & $7 / 19$ & $2 / 19$ & $374.3 \pm 90.3$ & $328.7 \pm 133.2$ \\
\hline$P$ value & $<.001$ & .007 & .002 & .588 & .221 & .558 & $<.001$ & .002 \\
\hline
\end{tabular}

Data are shown as means \pm SD or *absolute frequency. Post/pre BW, Postoperative/preoperative body weight percentage ratio at 6 hours after admission into the PICU.

received vasoactive drugs (dopamine and/or milrinone and/or adrenaline) if needed. Sedation and analgesia were achieved with midazolam and fentanyl, which were slowly tapered before extubation. Blood transfusions were administered if needed. Total parenteral nutrition was begun if enteral nutrition was not initiated 72 hours after the operation. No immunosuppressive or anti-inflammatory drug was administered. Blood gas analysis was performed after induction of anesthesia, during CPB, after separation of CPB, and during PICU admission. Systemic arterial pressure, right atrial pressure, colloid or donor blood volumes administered, postoperative blood loss, duration of mechanical ventilation, and days of PICU admittance were also recorded. The ratio of arterial partial pressure of oxygen to fractional inspired oxygen concentration $\left(\mathrm{PaO}_{2} / \mathrm{FIO}_{2}\right)$ was calculated at $1,3,6,12$, and 18 hours after admission to the PICU. The postoperative/preoperative body weight percentage ratio as an indicator of postoperative body weight gain was determined 6 hours after admission to the PICU.

\section{Blood Samples}

Blood samples for IL-10, IFN- $\gamma$, and cortisol determinations were taken as follows: shortly after anesthetic induction before sternotomy (T0), at admission to the PICU (30 minutes postoperatively, T1), 24 hours after onset of the operation (T2), and 3 days after the operation (T3). The serum samples were obtained in all children at each time point. Blood samples were collected in sterile vacuum tubes and immediately centrifuged $(1500 \mathrm{~g}$ for 20 minutes at $4^{\circ} \mathrm{C}$ ). Three aliquots of serum were obtained from each sample and stored at $-70^{\circ} \mathrm{C}$ until analysis. Simultaneous blood samples were taken as follows: for Coulter counter analysis of total leukocyte concentration, platelet count, and hemoglobin concentration; aspartate aminotransferase and alanine aminotransferase activities; creatinine and blood urea nitrogen concentrations; and hemostasis test (including fibrinogen, prothrombin time, and partial thromboplastin time). Serum cortisol levels were assayed by means of radioimmunoassay (Immulite 2000 Cortisol; Diagnostic Products Corporation, Los Angeles, Calif). The sensitivity of the radioimmunoassay for cortisol is $0.2 \mu \mathrm{g} / \mathrm{dL}$.

\section{Cytokine Analysis}

The amount of IL-10 and IFN- $\gamma$ present in serum samples was measured with an enzyme-linked immunosorbent assay (human IL-10, Bender Medsystems, Vienna, Austria; human IFN- $\gamma$, Endogen, Cambridge, Mass), as previously described. ${ }^{27}$ In brief, known concentrations of recombinant human IL-10 or IFN- $\gamma$ and the experimental samples were added in duplicate and incubated in polystyrene microtiter plates coated with a murine monoclonal antibody against the appointed cytokine, followed by incubation with an enzyme-linked polyclonal antibody directed to the cytokine. Next, a substrate solution for the enzyme was added, and the color development was stopped by adding $2 \mathrm{~N} \mathrm{H}_{2} \mathrm{SO}_{4}$. The absorbance was measured with a microtiter plate spectrophotometer. The amount of IL-10 or IFN- $\gamma$ present in each sample was determined from a standard curve generated in each assay and expressed as picograms per milliliter. The sensitivity of the enzyme-linked immunosorbent assay for IL-10 is $1.5 \mathrm{pg} / \mathrm{mL}$, and the sensitivity for IFN- $\gamma$ is $5 \mathrm{pg} / \mathrm{mL}$. The reproducibility of all measurements was within $10 \%$ in our laboratory.

\section{Statistical Analysis}

Statistical analysis was performed on personal computers with commercially available software (SPSS 8.0 software, Chicago, Ill). Results in the text and tables are expressed as means \pm SD or as absolute frequency. For the analysis of normally distributed data (as evidenced by the Kolmogorov-Smirnov test), we used the independent-samples $t$ test for comparison of values between the groups. The covariate analysis for the repeated-measures data on each subject was performed by using the general linear model repeated-measures procedure with simple contrasts, in which the reference category was the first category (T0). The $\chi^{2}$ test (with the Fisher exact test if necessary) was used in the analysis of the qualitative data. The Mann-Whitney $U$ test was used for the analysis of nonnormally distributed data. Correlation was studied with the Pearson correlation test (analyzing cytokines and cortisol serum levels at $\mathrm{T} 1$ ).

\section{Results \\ Postoperative Clinical Data}

All patients survived during the study period. We found differences in several clinical parameters after the surgical aggression between neonates and nonneonate patients, with both the level of pulmonary dysfunction and the postoperative/preoperative body weight percentage ratio being significantly higher in neonates than in the other children (Table 2). Moreover, length of both intubation time and stay in the PICU were also significantly longer in neonates (Table 2). On the other hand, although not statistically significant, there was a clear trend for the group of newborns to require 
TABLE 3. IL-10, IFN- $\gamma$, and cortisol serum levels in the pediatric patients before and after cardiac surgery

\begin{tabular}{lccr}
\hline & Neonates $(\mathbf{n}=\mathbf{8})$ & Nonneonates $(\mathbf{n}=\mathbf{1 9})$ & $\boldsymbol{P}$ value \\
\hline IL-10 $(\mathrm{pg} / \mathrm{mL})$ & & & \\
T0 & $1.87 \pm 0.51$ & $1.89 \pm 0.88$ & .923 \\
T1 & $52.79 \pm 18.98$ & $17.47 \pm 7.36$ & .001 \\
T2 & $8.91 \pm 1.92$ & $2.96 \pm 1.55$ & $<.001$ \\
T3 & $8.47 \pm 2.00$ & $2.30 \pm 0.88$ & $<.001$ \\
IFN- $\gamma(\mathrm{pg} / \mathrm{mL})$ & & & \\
T0 & $6.89 \pm 1.80$ & $6.40 \pm 1.37$ & .447 \\
T1 & $7.97 \pm 1.42$ & $19.91 \pm 3.48$ & $<.001$ \\
T2 & $6.22 \pm 1.30$ & $6.37 \pm 1.13$ & .781 \\
T3 & $7.26 \pm 1.36$ & $6.03 \pm 1.26$ & .060 \\
Cortisol $(\mu \mathrm{g} / \mathrm{dL})$ & & & \\
T0 & $11.64 \pm 1.88$ & $12.77 \pm 7.05$ & .522 \\
T1 & $29.98 \pm 4.69$ & $30.72 \pm 8.23$ & .815 \\
T2 & $21.35 \pm 5.37$ & $18.98 \pm 3.3$ & .276 \\
T3 & $18.49 \pm 3.75$ & $19.61 \pm 3.74$ & .483 \\
\hline
\end{tabular}

Data are shown as means \pm SD of the serum levels in each pediatric group. TO, Before sternotomy; $T 1$, at PICU arrival; $T 2,24$ hours after onset of the operation; $T 3,3$ days after the operation.

higher doses of vasoactive drugs and to have more infectious complications (Table 2).

\section{Open Cardiac Surgery Induces Different Patterns of IL-10 Response in Newborns and Other Pediatric Patients}

IL-10 serum levels in the 2 groups of patients analyzed before sternotomy (T0), at admission to the PICU (T1), 24 hours after onset of the operation (T2), and 3 days after the operation (T3) are demonstrated in Figure 1 and Table 3. There were no significant differences in IL-10 levels between the series of subjects at $\mathrm{T} 0$. At admission to the PICU, IL-10 serum concentrations increased significantly and reached the peak level during the whole study period in the 2 groups of patients $(P<.001)$. Interestingly, at this time (T1), the serum value of IL-10 was markedly higher in neonates than in the other group of subjects $(P=.001)$. Subsequently, IL-10 serum levels declined at T2 and T3 in both groups, although newborns still demonstrated significantly higher levels of IL-10 than the other pediatric patients $(P<.001)$. Although in neonates IL-10 serum concentrations remained significantly elevated from $\mathrm{T} 0$, in older children IL-10 serum levels dropped to the level found at $\mathrm{T} 0$.

\section{Neonates Did Not Show Changes in IFN- $\gamma$ Serum} Levels as a Response to Cardiac Surgery

As shown in Table 3, no significant changes in IFN- $\gamma$ serum levels were observed in neonates across the measurements. In contrast, nonneonate patients demonstrated a significant increase in IFN- $\gamma$ serum levels at T1 compared with that at
NEONATES

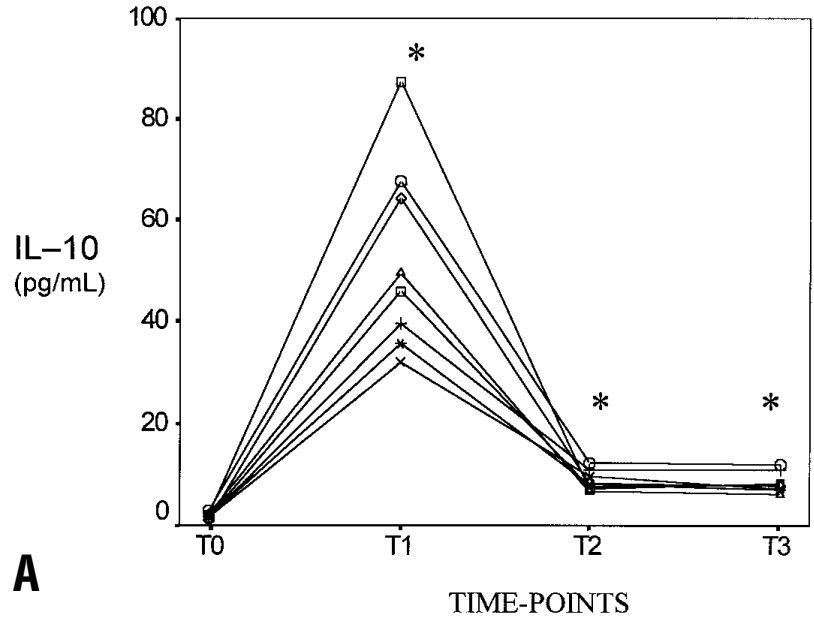

NON-NEONATES

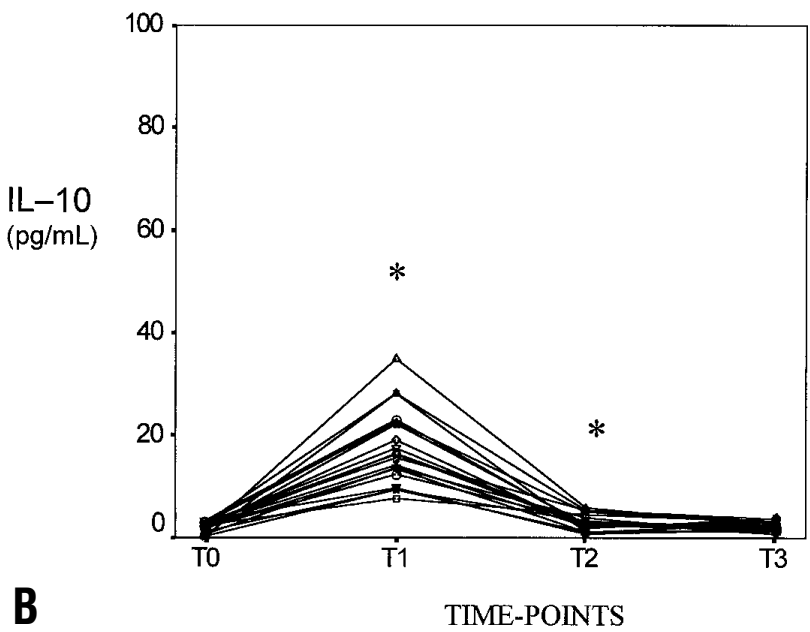

Figure 1. IL-10 serum levels in the 2 groups of pediatric patients. Lines and symbols show individual values. TO, Before sternotomy; T1, at PICU arrival; T2, 24 hours after onset of the operation; T3, 3 days after the operation. *Significant increase with respect to TO IL-10 serum levels.

T0 $(P<.001)$. It should be emphasized that at T1 IFN- $\gamma$ serum concentrations in nonneonate children were significantly higher than those found in newborn patients $(P<$ .001). Subsequently, at T2 and T3, IFN- $\gamma$ serum levels in the nonneonate group decreased to values similar to those detected at $\mathrm{T} 0$.

\section{Cortisol Secretion in Response to CPB Is Preserved in All Pediatric Patients}

We were next interested in whether cortisol secretion could be associated with the distinct patterns of IL-10 and IFN- $\gamma$ 
TABLE 4. Clinical significance of peak IL-10 serum levels at T1

\begin{tabular}{lrr}
\hline & \multicolumn{1}{c}{ Neonates } & Nonneonates \\
\hline CPB time & $0.501(.206)$ & $0.253(.297)$ \\
Crossclamp time & $-0.448(.266)$ & $0.283(.240)$ \\
Minimum temperature on bypass & $0.526(.180)$ & $-0.194(.426)$ \\
Post/pre BW (\%) & $0.739(.036)$ & $0.097(.692)$ \\
Mechanical ventilation time & $-0.295(.477)$ & $0.610(.006)$ \\
Days of PICU stay & $-0.206(.625)$ & $0.634(.004)$ \\
Postoperative blood loss at & $-0.287(.490)$ & $0.300(.213)$ \\
$\quad$ first day & & \\
$\mathrm{PaO}_{2} / \mathrm{FIO}_{2}$ at third hour & $-0.753(.031)$ & $-0.506(.027)$ \\
$\mathrm{PaO}_{2} / \mathrm{FIO}_{2}$ at $18 \mathrm{hours}$ & $-0.785(.021)$ & $-0.671(.006)$ \\
Dopamine $10 \mu \mathrm{g} \cdot \mathrm{kg}^{-1} \cdot \mathrm{min}^{-1} \mathrm{vs}$ & $63.0 \pm 16.6 \mathrm{vs}$ & $21.9 \pm 7.2 \mathrm{vs}$ \\
$\quad$ dopamine $<10 \mu \mathrm{g} \cdot \mathrm{kg}^{-1} \cdot \mathrm{min}^{-1 *}$ & $35.8 \pm 3.7(.036)$ & $14.9 \pm 6.3(.028)$
\end{tabular}

Data represent Pearson correlation coefficients ( $P$ values). T1, At PICU arrival; Post/pre $B W$, postoperative/preoperative body weight percentage ratio at 6 hours after admission into the PICU.

*Statistical association: data represent means $\pm \mathrm{SD}$, with $P$ value in parentheses.

serum concentrations observed in the different groups of pediatric patients. As Table 3 shows, the levels of cortisol before sternotomy (T0) were not significantly different between the 2 groups of patients. After CBP at T1, cortisol serum concentrations in the 2 groups show a clear increase with respect to values obtained at T0 $(P<.001)$. Subsequently, at T2 and T3, cortisol levels markedly declined in all patients. Still, these values remained significantly higher than those found at T0 in both newborns $(P=$ .001 and $P<.001)$ and older children $(P=.001$ and $P=$ $.002)$. It is noteworthy that after $\mathrm{CPB}$, there were no significant differences in serum cortisol concentrations between the 2 groups of subjects at the distinct moments analyzed (T1, T2, and T3; Table 3).

\section{Clinical Significance of Cytokines and Cortisol Serum Levels}

First, in the nonneonate group there were no significant differences between children with or without preoperative cyanosis with respect to serum concentrations at T1 of IL$10(19.78 \pm 7.17 \mathrm{pg} / \mathrm{mL}$ vs $16.65 \pm 7.51 \mathrm{pg} / \mathrm{mL}, P=.298)$, IFN- $\gamma(17.55 \pm 4.09 \mathrm{pg} / \mathrm{mL}$ vs $20.75 \pm 2.95 \mathrm{pg} / \mathrm{mL}, P=$ $.087)$, and cortisol $(34.86 \pm 10.58 \mu \mathrm{g} / \mathrm{dL}$ vs $29.24 \pm 7.10$ $\mu \mathrm{g} / \mathrm{dL}, P=.391)$.

The potential correlation in each group of patients between both surgical and postoperative clinical parameters and peak IL-10 serum levels at T1 is shown in Table 4. It should be emphasized that there were no correlations between surgical variables (CPB time, crossclamp time, and depth of intraoperative hypothermia) and peak IL-10 serum levels in either neonates or older children. Moreover, the presence or absence of circulatory arrest in newborn patients during CBP was not related to serum concentrations of IL-10 at T1 $(45.32 \pm 16.89 \mathrm{pg} / \mathrm{mL}$ vs $57.28 \pm 20.51$ $\mathrm{pg} / \mathrm{mL}, P=.393)$. Interestingly, in the group of neonates we found significant positive correlations between peak IL-10 serum levels and both $\mathrm{PaO}_{2} / \mathrm{FIO}_{2}$ ratio and postoperative/ preoperative body weight percentage ratio, suggesting a possible relation of IL-10 response with pulmonary dysfunction associated with capillary leak syndrome. In nonneonate patients there were also correlations between peak IL-10 serum levels and $\mathrm{PaO}_{2} / \mathrm{FIO}_{2}$ ratio. However, in this group of children we found no correlations between this cytokine and body weight gain.

In addition to these remarkable correlations, there was also significant association between the need for high doses of vasoactive drugs (ie, dopamine $>10 \mu \mathrm{g} \cdot \mathrm{kg}^{-1} \cdot \mathrm{min}^{-1}$ or epinephrine in any dose) and peak IL-10 serum levels at T1 in both neonates $(P=.036)$ and children $(P=.028)$. On the other hand, only in nonnewborn children were peak IL-10 concentration levels correlated with both length of mechanical ventilation and stay in the PICU. The absence of correlations between these parameters in neonate patients could be ascribed to the fact that weaning of mechanical ventilation in these children is frequently conditioned by other problems not related to pulmonary dysfunction, such as decreased functional residual capacity, elevated compliance of the chest wall, and predisposition to bronchopulmonary collapse.

With regard to IFN- $\gamma$ and cortisol serum concentrations, we found no correlations among these parameters at $\mathrm{T} 1$ and either surgical or postoperative clinical variables (data not shown). However, the 2 nonneonate patients with respiratory infections during the postoperative period showed low peak IFN- $\gamma$ serum levels (14.92 and $15.37 \mathrm{pg} / \mathrm{mL}$, respectively).

No correlations were observed between cortisol and IL10 or IFN- $\gamma$ serum levels in either of the 2 patient groups evaluated (data not shown).

\section{Discussion}

In this article we have demonstrated that tissue injury induced by cardiac surgery in pediatric patients is associated with profound modifications in IL-10 and IFN- $\gamma$ serum levels that are mainly related to the age of the children.

Our results show that surgical cardiac stress promotes a significant increase of IL-10 serum levels in children, regardless of their age, nutritional status, preoperative clinical condition, or the magnitude of surgical injury. It should be emphasized that newborn patients undergoing cardiac surgery display greater amounts of serum IL-10 than older children at each postoperative time point analyzed. In contrast, IFN- $\gamma$ serum levels detected in neonates did not show significant changes after cardiac surgery. Interestingly, in the other groups of pediatric patients, a clear increase of serum IFN- $\gamma$ was observed in the immediate postoperative period. 
In our group of nonneonate patients, there were no significant associations between IFN- $\gamma$, IL-10, or cortisol serum concentrations and previous presence or absence of congenital cyanotic heart disease. Importantly, the unusual pattern of IFN- $\gamma$ and IL-10 serum release detected in neonates cannot be ascribed to changes in pituitary-adrenal response, as evaluated with serum cortisol levels.

The pattern of response of IL-10 to CPB procedures in newborns has not been previously analyzed. However, our findings in nonneonate children do agree with the results of the few published studies ${ }^{28-30}$ that address IL-10 production in response to $\mathrm{CPB}$ procedures in children. We have found no prior studies investigating the response of IFN- $\gamma$ induced by cardiac surgery in pediatric patients. IFN- $\gamma$ serum concentrations induced by $\mathrm{CBP}$ have been only reported in adults, whose patterns of IFN- $\gamma$ response are similar to those observed in our series of nonneonate patients. ${ }^{31}$

There were no correlations between either peak IL-10 or IFN- $\gamma$ serum levels and CPB time, crossclamping time, minimum temperature on $\mathrm{CPB}$, and circulatory arrest in either neonates or the other pediatric patients. The distinctive pattern of IL-10 production seen in neonates compared with that in nonnewborn children could not be ascribed to grouprelated differences in the preoperative clinical condition or surgical parameters tested. In support of this evidence it can be argued that pediatric patients from the nonneonate group show similar serum concentrations of these cytokines in spite of striking surgical stress differences.

The potential clinical relevance of this distinctive pattern of IL-10 and IFN- $\gamma$ responses to cardiac surgery in neonates has also been evaluated in our study. Interestingly, in neonates there was a marked correlation among peak IL-10 serum levels and both pulmonary dysfunction and postoperative weight gain, suggesting an intriguing possible implication of this cytokine in the physiopathology of capillary leak syndrome, which is associated with CBP in newborn patients. In line with this presumption, it should be pointed out that older children also showed significant correlation between IL-10 serum concentrations and pulmonary dysfunction. Nevertheless, taking into account that the group of neonates exhibited higher IL-10 serum levels and more complications related to capillary leak syndrome, it is conceivable that IL-10 response could play a critical role in the postoperative course of newborn patients. Moreover, in both groups of children, there was also a significant association between the need for high doses of vasoactive drugs and IL10 serum concentrations, providing additional proof of the potential involvement of IL-10 in the systemic inflammatory response linked to CBP in pediatric patients.

Recent studies have provided evidence that in the active phase of other severe systemic inflammatory diseases, the production of IL-10 is also increased. In septic shock, for instance, high IL-10 serum levels are related with concomi- tant increased release of proinflammatory cytokines and greater clinical severity and mortality. ${ }^{32-34}$ Given the biologic evidence that IL-10 acts as an inhibitory functional peptide on activated macrophages and $\mathrm{T}$ lymphocytes that secrete proinflammatory cytokines, it is reasonable to propose that increases in this cytokine reflect a mechanism of counterregulation to limit the systemic effects of an inappropriate and deleterious biologic response. The fact that neonates display more extensive and sustained IL-10 serum levels induced by cardiac surgery supports the view advocated by other investigators that, in this early period of the life, the biologic response is more severe. ${ }^{17-19,24}$ However, it cannot be excluded that IL-10 might directly mediate harmful effects, as has been indicated in some multiorgan diseases, such as systemic lupus erythematosus. ${ }^{35}$

On the other hand, the clinical significance of the absence of IFN- $\gamma$ release in newborn patients undergoing cardiac surgery could be relevant, conditioning the course of the systemic biologic response. In this regard it is possible to suggest that this lack of IFN- $\gamma$ response could predispose to serious infectious diseases that can complicate the postoperative period in neonate patients. In support of this hypothesis, it can be argued that older children with infectious complications displayed low peak IFN- $\gamma$ serum concentrations. Whether this deficient neonatal IFN- $\gamma$ response to an aggressive surgical stimulus is intrinsic or the result of a suppressor hyperresponse of IL-10 on IFN- $\gamma$ production is unknown. Nevertheless, it is noteworthy that in previous reports stimulated peripheral mononuclear cells from healthy neonates exhibited decreased capacity for IFN- $\gamma$ secretion. $^{24}$

It is clear that other peptides that make up the cytokine and chemokine families could be implicated in the regulation of the biologic response associated with tissue injury. ${ }^{7,9}$ Nevertheless, the data are still fragmentary, and much more information will be needed before reaching any definitive conclusions.

An important question that has to be elucidated is the source for the striking IL-10 serum levels induced by CPB in neonates. The potential producer cells are not unique and include monocytes-macrophages and both $\mathrm{T}$ and $\mathrm{B}$ cells. Taking into account that IL-10 peak levels are achieved immediately after surgical intervention, it is likely that in this phase of the biologic response, activated monocytesmacrophages are the main producers of IL-10. However, our results show that newborn patients exhibit sustained elevated IL-10 serum concentrations for 72 hours after cardiac surgery. This finding is consistent with the presumption that T lymphocytes, and perhaps also B cells, activated later might be implicated in the secretion of IL-10. On the basis of this presumption, it is reasonable to postulate that major surgical stress could promote a predominant $\mathrm{T}_{\mathrm{H}} 2$ functional response in neonates. This possibility is further supported 
by the observation that these patients do not display measurable amounts of the IFN- $\gamma \mathrm{T}_{\mathrm{H}} 1$ cytokine in serum.

In summary, this study expands current knowledge on the state of systemic biologic response to $\mathrm{CPB}$ in pediatric patients and demonstrates the presence of a distinctive pattern of IFN- $\gamma$ and IL-10 release in neonates with potential prognostic implications. Future investigations will be necessary to identify the pathogenic and clinical significance of this cytokine imbalance, which may provide a rationale for new immunologic approaches to selected newborn patients with severe systemic inflammatory responses to cardiac surgery.

We thank Maria Dolores Vigil, MD, PhD, Gregorio Marañón University Hospital, for statistical advice and the nursing staff of the intensive care unit for their continuous support.

\section{References}

1. Chrousos GP. The hypothalamic-pituitary-adrenal axis and immunemediated inflammation. $N$ Engl J Med. 1995;332:1351-62.

2. Sternberg EM, Chrousos GP, Wilder RL, Gold PW. The stress response and regulation of inflammatory disease. Ann Intern Med. 1992;117:854-66.

3. McEwen BS. Protective and damaging effects of stress mediators. $N$ Engl J Med. 1998;338:171-9.

4. Bellón LM, Manzano L, Bernardos L, Garcia-Honduvilla N, Larrad A, Bujan J, et al. Cytokine levels after open and laparoscopic cholecystectomy. Eur Surg Res. 1997;29:27-34.

5. Asimakopoulos G, Smith PL, Ratnatunga CP, Taylor KM. Lung injury and acute respiratory distress syndrome after cardiopulmonary bypass. Ann Thorac Surg. 1999;68:1107-15.

6. Hill GE. Cardiopulmonary bypass-induced inflammation: is it important? J Cardiothorac Vasc Anesth. 1998;12(suppl 1):21-5.

7. Wan S, LeClerc JL, Vincent JL. Inflammatory response to cardiopulmonary bypass. Mechanism involved and possible therapeutic strategies. Chest. 1997;112:676-92.

8. Miller BE, Levy SH. The inflammatory response to cardiopulmonary bypass. J Cardiothorac Vasc Anesth. 1997;11:355-66.

9. Mayers I, Johnson D. The nonspecific inflammatory response to injury. Can J Anaesth. 1998;45:871-9.

10. Kawahito K, Kobayashi E, Ohmori M, Harada K, Kitoch Y, Fujimura A, et al. Enhanced responsiveness of circulatory neutrophils after cardiopulmonary bypass: increased aggregability and superoxide producing capacity. Artif Organs. 2000;24:37-42.

11. Dinarello CA. Role of pro- and anti-inflammatory cytokines during inflammation: experimental and clinical findings. J Biol Regul Homeost Agents. 1997;11:91-103.

12. Romagnani S. The Th1/Th2 paradigm. Immunol Today. 1997;18:263-6.

13. Del Prete G. The concept of type- 1 and type- 2 helper T cells and their cytokines in humans. Int Rev Immunol. 1998;16:427-55.

14. Stordeur P, Goldman M. Interleukin-10 as a regulatory cytokine induced by cellular stress: molecular aspects. Int Rev Immunol. 1998; 16:501-22.

15. Opal SM, DePalo VA. Anti-inflammatory cytokines. Chest. 2000;117: 1162-72.

16. Boehm U, Klamp T, Groot M, Howard JC. Cellular responses to interferon-gamma. Апnи Rev Immunol. 1997;15:749-95.
17. Jones MO, Pierro A, Hammond P, Lloyd DA. The metabolic response to operative stress in infants. J Pediatr Surg. 1993;28:1258-63.

18. Okur H, Kucukaydin M, Ustdal KM. The endocrine and metabolic response to surgical stress in the neonate. J Pediatr Surg. 1995;30: 626-30.

19. Schelonka RL, Infonte AJ. Neonatal immunology. Semin Perinatol. 1998;22:2-14

20. Lilic D, Cant AJ, Abinum M, Calnert JE, Spickett GP. Cytokine production differs in children and adults. Pediatr Res. 1997;42:237-40.

21. Sancho L, de la Hera A, Casas J, Vaquer S, Martínez C, Alvarez-Mon $\mathrm{M}$. Two different maturational stages of natural killer lymphocytes in human newborn infants. J Pediatr. 1991;119:446-54.

22. Sancho L, Martínez C, Nogales A, de la Hera A, Alvarez-Mon M. Reconstitution of natural killer activity in the newborn by interleukin2. N Engl J Med. 1986;314:57-8.

23. Vigano A, Esposito LM, Arienti D, Zagliani A, Massironi E, Principi N, et al. Differential development of type 1 and type 2 cytokines and beta-chemokines in the ontogeny of healthy newborns. Biol Neonate. 1999;75:1-8.

24. Scott ME, Kubin M, Kohl S. High level interleukin-12 production, but diminished interferon-gamma production, by cord blood mononuclear cells. Pediatr Res. 1997;41:547-53.

25. Mitchell IM, Logan RW, Pollock JC, Jamieson MPG. Nutritional status of children with congenital heart disease. Br Heart J. 1995;73:27783.

26. Doherty JF, Golden MHN, Remick DG, Griffin GE. Production of interleukin- 6 and tumour necrosis factor- $\alpha$ in vitro is reduced in whole blood of severely malnourished children. Clin Sci. 1994;86:347-51.

27. Román LI, Manzano L, de la Hera A, Abreu L, Rossi I, Alvarez-Mon $\mathrm{M}$. Expanded $\mathrm{CD} 4+\mathrm{CD} 45 \mathrm{RO}+$ phenotype and defective proliferative response in T lymphocytes from patients with Crohn's disease. Gastroenterology. 1996;110:1008-19.

28. Sugita T, Watasida s, Katsuyama K, Nakajima Y, Yamamoto R, Mori A. Interleukin-10 concentration in children undergoing cardiopulmonary bypass. J Thorac Cardiovasc Surg. 1996;112:1127-8.

29. Tarnok A, Hambsch J, Schneider P. Cardiopulmonary bypass-induced increase of serum IL-10 levels in children. J Thorac Cardiovasc Surg. 1998; 115:475-7.

30. Seghaye MC, Duchateau J, Bruniaux J, Demontoux S, Borson C, Serraf A, et al. Interleukin-10 release related to cardiopulmonary bypass in infants undergoing cardiac operations. J Thorac Cardiovasc Surg. 1996;111:545-53.

31. Markewitz A, Faist E, Lang S, Endres S, Fuchs D, Reichart B. Successful restoration of cell-mediated immune response after cardiopulmonary bypass by immunomodulation. $J$ Thorac Cardiovasc Surg. 1993;105:15-24.

32. Van Deuren M, van der Ven-Jongekrijg J, Bartelink AKM, van Dalen R, Sanerwein RW, van der Meer JWH. Correlation between proinflammatory cytokines and antiinflammatory mediators and the severity of disease in meningococcal infections. J Infect Dis. 1995;172: 433-9.

33. Lehmann AK, Halstensen A, Sornes S, Rokke O, Waage A. High levels of interleukin 10 in serum are associated with fatality in meningococcal disease. Infect Immun. 1995;63:2109-12.

34. Dougthy L, Carcillo JA, Kaplan S, Janosky J. The compensatory antiinflammatory cytokine interleukin 10 response in pediatric sepsisinduced multiple organ failure. Chest. 1998;113:1625-31.

35. Grondal G, Kristjansdottir H, Gunnlaugsdottir B, Arnason A, Lundberg I, Klareskog L, et al. Increased number of interleukin-10producing cells in systemic lupus erythematosus patients and their first-degree relatives and spouses in Icelandic multicase families. Arthritis Rheum. 1999;42:1649-54. 